\title{
Adventitious agent contamination risk mitigation: engineering MMV virus resistance into $\mathrm{CHO}$ cells
}

Joaquina X Mascarenhas ${ }^{1 *}$, Lisa Burger², Ademola Kassim, Trissa Borgschulte', Delia Lyons', Henry George, Nan Lin ${ }^{1}$, Audrey Chang ${ }^{3}$, David Onions ${ }^{3}$, David Pintel ${ }^{2}$, Kevin. Kayser ${ }^{1}$

From 24th European Society for Animal Cell Technology (ESACT) Meeting: C2P2: Cells, Culture, Patients, Products Barcelona, Spain. 31 May - 3 June 2015

\section{Background}

The introduction of animal origin free (AOF) media has significantly reduced the incidence of adventitious virus contamination in biological production systems. Nevertheless, contamination by the parvovirus Mouse Minute Virus (MMV) remains a continuing challenge. Although infrequent, infection of a fermenter can be catastrophic for a manufacturer, and can also have a potential impact on drug supply, patient safety and have regulatory implications.

In this work, we evaluated engineering Chinese Hamster Ovary $(\mathrm{CHO})$ cell lines to create a new host cell line that

\begin{tabular}{|c|c|c|c|c|}
\hline CHO Genotype & Wild Type CHO & Slc35A1- & COSMC- $^{-}$ & $\begin{array}{c}\mathrm{St}_{3 \mathrm{Gal}} 4^{--} \text {and } \\
\mathrm{St} 3 \mathrm{Gal}^{-/-}+ \\
\mathrm{St} 3 \mathrm{Gall}^{-/}\end{array}$ \\
\hline \multicolumn{5}{|c|}{ Glycosylation structure } \\
\hline N-linked (Asn) & : & $\begin{array}{l}8 \\
8 \\
8 \\
8\end{array}$ & $\begin{array}{l}: 8: \\
: 8 \\
: 8\end{array}$ & 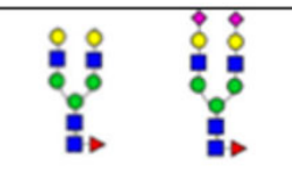 \\
\hline $\begin{array}{l}\text { O-linked (Ser- } \\
\text { Thr) }\end{array}$ & 웅 & 임 & $\checkmark$ & \&े \\
\hline $\begin{array}{l}\text { Glycosylation } \\
\text { Phenotype }\end{array}$ & $\begin{array}{l}\text { N-linked and O- } \\
\text { linked WT }\end{array}$ & Asialylated & $\begin{array}{l}\text { N-linked WT } \\
\text { O-linked } \\
\text { truncated }\end{array}$ & $\begin{array}{l}\text { Mixture of } \\
\text { different } \\
\text { asialylated } \\
\text { structures }\end{array}$ \\
\hline
\end{tabular}

Figure 1 ZFN mediated gene knock outs affecting terminal sialic acid on glycosylation structures tested for susceptibility to MMV infection

${ }^{1}$ Cell Sciences and Development, SAFC Sigma Aldrich, Saint Louis, Missouri,

63117, USA

Full list of author information is available at the end of the article

(c) 2015 Mascarenhas et al. This is an Open Access article distributed under the terms of the Creative Commons Attribution License 


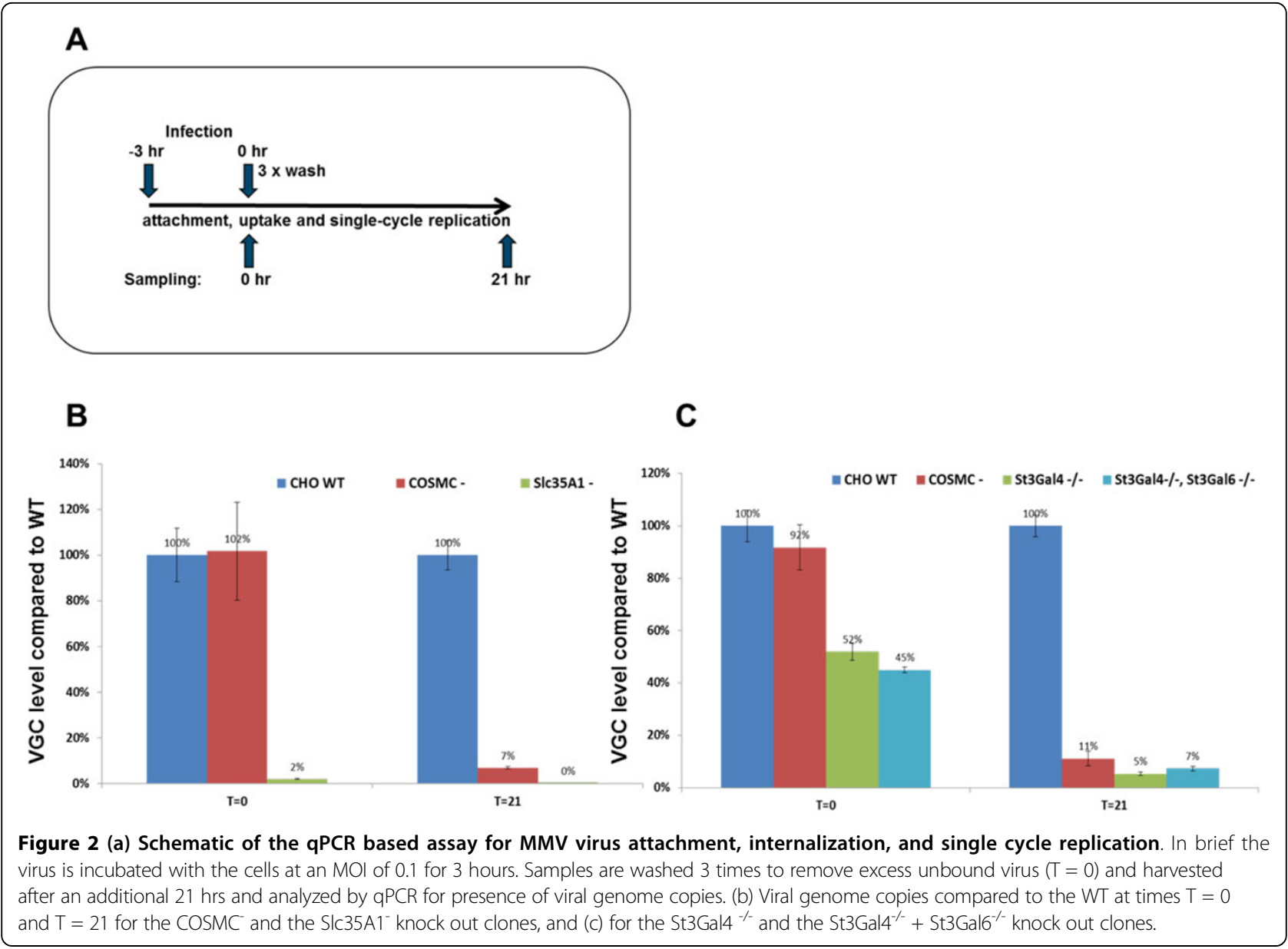

would be resistant to MMV infection by modifying the major receptors used by the virus to enter cells. The goal was to engineer a host cell line resistant to MMV infection, while maintaining productivity and product quality profiles. Our strategy is outlined below.

Attachment to a cell surface receptor is a key first step in the infection cycle for viruses. While the exact functional receptor for MMV binding to $\mathrm{CHO}$ cell surface is unknown, sialic acid on the cell surface has been implicated [1]. Moreover, MMV has been shown to preferentially bind to $\alpha-2,3$ sialylated glycans with a type- 2 Gal 1 1-4GlcNAc motif. Our approach was to systematically knock out genes affecting sialylation and then challenge each cell line for their ability to resist viral entry. Figure 1 lists the genes that were knocked out by ZFN mediated cell line engineering, and the corresponding typical glycosylation phenotypes expected on $\mathrm{N}$-linked and O-linked glycans.

MMV infectivity studies were conducted on the knock out clones identified in Figure 1 at various multiplicities of infection e.g. 0.1 viruses per cell, far higher than would be encountered in a fermenter infection. Infection of the cells was analyzed by PCR for the presence of viral genomic sequences as described in the schematic in Figure 2.

\section{Results}

$\mathrm{CHO}$ cell lines engineered to express lower surface sialic acid demonstrate increased resistance to MMV infection compared to the wild-type controls. While the complete absence of sialic acid on the SLC35A1 knock-out cell line led to almost complete resistance to MMV infection, the COSMC knock out clones were about $10 \mathrm{x}$ more resistant to MMV infection. The knock out of the COSMC gene exclusively truncates O-glycosylation, leaving the $\mathrm{N}$-glycosylation pathway and the terminal sialic acids intact. The lower levels of cell surface sialic acid however, were able to confer the $10 \mathrm{x}$ resistance to MMV infection. Moreover, the Slc35A1 knock-out appears to result in complete abrogation of binding of the virus to the cell surface, even at time $\mathrm{T}=0$. The COSMC knock-out on the other hand appears to affect virus internalization and replication rather than initial binding of the virus to the cell surface. In contrast, the St3Gal4 -/- and the St3Gal4-/- + St3Gal6-/- knock-out 
clones appear to affect both cell surface binding as well as the internalization of the MMV virus, with the cumulative effect being similar to that of the COSMC knock-out.

\section{Conclusions}

Our data demonstrate that viral resistance against MMV virus can be incorporated into $\mathrm{CHO}$ production cell lines, adding another level of "defense", against the devastating financial consequences of this virus infection. While the importance of cell surface sialic acid for virus binding and internalization is clearly evident, further studies on the downstream steps of the MMV life cycle may provide further targets for interrupting and eliminating the infection process, thus conferring a higher degree of resistance.

\section{Authors' details}

${ }^{1}$ Cell Sciences and Development, SAFC Sigma Aldrich, Saint Louis, Missouri, 63117, USA. ${ }^{2}$ School of Medicine, University of Missouri, Columbia, Missouri, 65211, USA. ${ }^{3}$ Bioreliance, SAFC Sigma Aldrich, Rockville, Maryland, 20850,

USA

Published: 14 December 2015

\section{References}

1. Cotmore SF, Tattersall P: Parvoviral host range and cell entry mechanisms. Adv Virus Res 2007, 70:183-232.

2. Nam HJ, Gurda-Whitaker B, Gan WY, llaria S, McKenna R, Mehta P, Alvarez RA, Agbandje-McKenna M: Identification of the sialic acid structures recognized by minute virus of mice and the role of binding affinity in virulence adaptation. J Biol Chem 2006, 281:25670-25677.

doi:10.1186/1753-6561-9-S9-O2

Cite this article as: Mascarenhas et al: Adventitious agent contamination risk mitigation: engineering MMV virus resistance into CHO cells. BMC Proceedings 2015 9(Suppl 9):O2.

\section{Submit your next manuscript to BioMed Central} and take full advantage of:

- Convenient online submission

- Thorough peer review

- No space constraints or color figure charges

- Immediate publication on acceptance

- Inclusion in PubMed, CAS, Scopus and Google Scholar

- Research which is freely available for redistribution

Submit your manuscript at www.biomedcentral.com/submit 